\title{
ASSESSMENT OF POLYETHYLEN-MODIFIED BITUMEN ADHESION USING COMPUTER IMAGE ANALYSIS
}

\section{BROŻYNA ${ }^{1}$, K. J. KOWALSKI ${ }^{2}$}

\begin{abstract}
In order to achieve extended life of asphalt pavement, one of key points is to achieve a good bonding between it's components. This research paper presents findings on the topic of influence of polyethylene bitumen modification on the adhesion between bitumen and aggregate. A novel method of quantifying the bitumen coated area, based on computer image analysis, has been developed for this study. Two different methods of adhesion testing were employed, namely boiling water method and the rolling bottle method. Aggregates used in this study were granite and limestone. Based on 108 measurements, it was concluded that polyethylene modification has a negative impact on binder aggregate adhesion.
\end{abstract}

Keywords: bitumen modification, polyethylene, computer image analysis, adhesion

\section{INTRODUCTION}

Due to the increasing traffic load and public expectations, engineers are faced with a challenge to design safe, durable and ecologically friendly roads [2, 4, 13 and 14]. Flexible asphalt pavements are constructed using asphalt mixture (also called as hot mix asphalt, HMA), a composite material consisting of an aggregate load bearing skeleton and a bitumen based matrix holding the aggregate. Due to the visco-elastic properties of bitumen, proper rheological modelling of HMA plays an important role in pavement design process [12 and 22]. One of the possible ways to improve mix durability is to increase quality requirements of materials with which the roads are paved. Since there is little to be done in terms of aggregate strength, current research is focused on designing high performance HMAs, mainly by proper bitumen modification, typically with commercially

\footnotetext{
${ }^{1}$ M.Sc. Eng., Warsaw University of Technology, Faculty of Civil Engineering

${ }^{2}$ Ph.D. Eng., assistant professor, Warsaw University of Technology, Faculty of Civil Engineering, office 540, al. Armii Ludowej 16, 00-637, Warsaw, Poland, k.kowalski@il.pw.edu.pl - corresponding author.
} 
available polymers (SBS) or rubber from waste tires [8 and 16]. Although improving strength performance of HMAs components is important, one must not forget that the later are destined to work as a composite, and because of that, a high adhesion between the HMA's components is of great importance.

\section{LITERATURE REVIEW}

Adhesion of bitumen binders to aggregate has been research by various teams around the globe [6, 10, 11, 18 and 20]. However, not much research has been done in terms of effects of polyethylene (PE) modification on bitumen aggregate adhesion [1]. PE modification of bitumen binder results in lower penetration and higher softening temperature, which are especially advantageous for hot climates [3, 7 and 21]. Based on the chemical bonding and electrostatic theories [9], it is expected that the addition of polyethylene to the asphalt binder will result in lower adhesion to the aggregate grains. Van der Waals forces describe the sum of attractive and repulsive forces, which origin from the intermolecular interactions. Since PEs' are built from non-polar hydrocarbons, their presence may mask the electro-statically active regions or a molecule, lowering the magnitude of van der Waals forces. This is not the only one theory explaining the phenomena of adhesion, other explanations may also be found [9], however for the scope of this paper the presented theory seems sufficient.

\section{RESEARCH PROGRAM}

The test program involved study of three types of bitumen and two types of aggregates. Two significantly different testing methods were utilized in the study for the adhesion assessment. In order to improve methods reliability, testing methods were modify by application of computer image analysis to quantify obtained results.

\subsection{MATERials}

In course of this research two different types of aggregate, namely granite and limestone, were coated with three different bitumens (one neat and two modified).

The base bitumen for this study was road bitumen 50/70 conforming all regulations according to PN-EN 12591:2010 specification “Asfalty i lepiszcza asfaltowe -- Wymagania dla asfaltów 
drogowych/Bitumen and bituminous binders - Specifications for paving grade bitumens”. Using this binder, three different bitumens were obtained for further tests. Two bitumens were laboratorymodified using pure polyethylene (additive A) and polyethylene copolymers (additive B). Detail properties of additives and modification procedure were described elsewhere [5]: neat bitumen was placed in a steel vessel and heated up to $180^{\circ} \mathrm{C}$, at which PE based additive was added (in the amount of $5 \% \mathrm{w} / \mathrm{w}$ ) to the mix and stirred using a high-shear mixer running at $4000 \mathrm{RPM}$ (Revolutions Per Minute) for the duration of three hours. The third bitumen binder (penetration 50/70) was left neat, in order to act as a benchmark to which the adhesion results for the two modified samples were to be compared. In order to cover wide range of aggregates, mineral material used in this study differed in terms of their overall silica oxide $\left(\mathrm{SiO}_{2}\right)$ content, where granite has high $\mathrm{SiO}_{2}$ concentration and limestone has low $\mathrm{SiO}_{2}$ concentration [20]. It is common knowledge that aggregates with low $\mathrm{SiO}_{2}$ content, so called alkaline rocks, exhibit higher adhesion towards asphalt binders as compared to the acidic counterparts. The gradation of the applied aggregate was limited to the $4 / 6,3$ fraction. All batches of aggregates were washed to remove any fine dust particles (which would inhibit proper adhesion) and dried at $120^{\circ} \mathrm{C}$ to remove all unbound water.

\subsection{EXPERIMENTAL PLAN}

The research consisted of materials' preparation and testing. In the first stage batches of granite and limestone were washed, dried and sieved in order to extract the 4/6,3 fraction. This stage was followed by bitumen preparation, which was later combined with the previously prepared aggregate. The next step consisted of testing the coated bitumen by means of bottle method and boiling method tests (six independent samples were used for each aggregate/bitumen/adhesion method combination). In the last stage washed area from the aggregate samples was quantified with the application of the computer image analysis. An overview of the experimental plan is presented in the Fig. 1. 


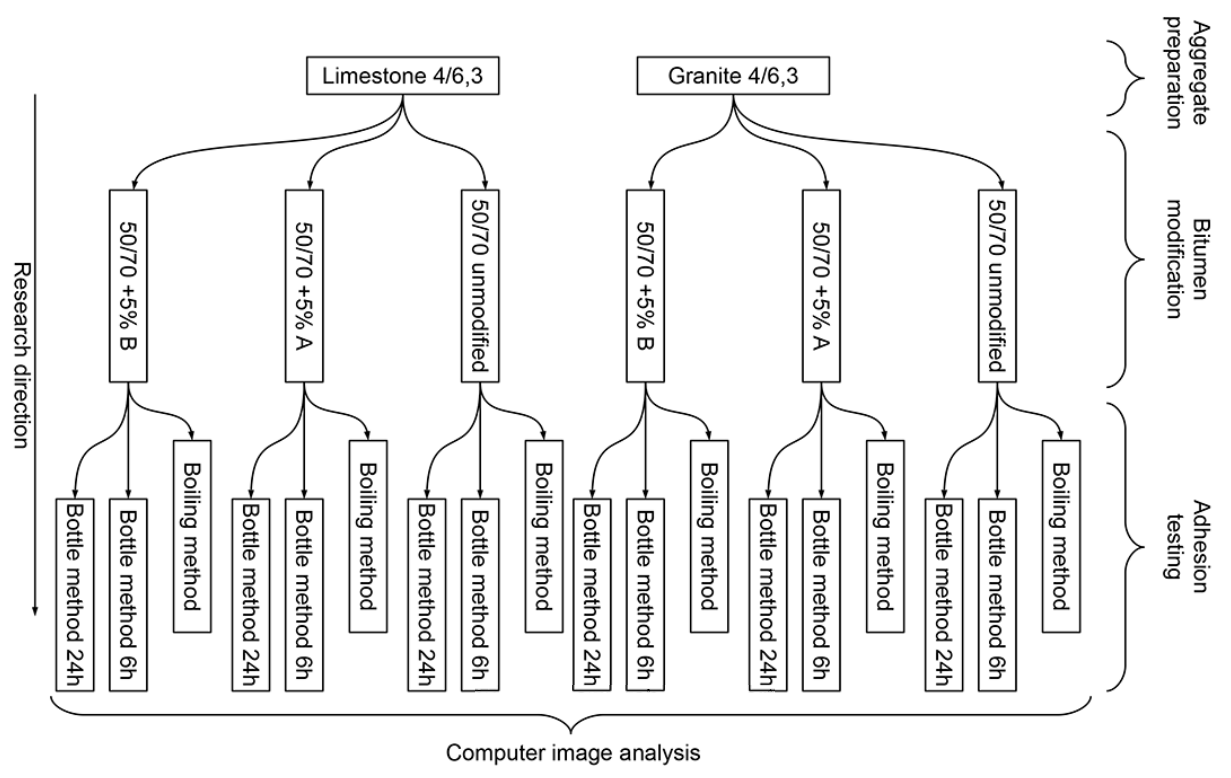

Fig. 1. Research flowchart

\subsection{TESTING METHODS FOR BITUMEN AGGREGATE ADHESION}

Two methods of adhesion testing were utilized in this study: boiling water and rolling bottle.

The boiling water method is based on a currently withdrawn old Polish standard (PN-84 B-06714/22 „Kruszywa mineralne. Badania. Oznaczanie przyczepności bitumów / Mineral aggregates. Tests. Assesment of bitumen adhesion”). According to this method a washed and dried sample of aggregate is uniformly coated by a specific amount of bitumen. Such specimen is then placed in a beaker and boiled in water for $10+3 \mathrm{~min}$. During the boiling process, loose particles of bitumen are removed from the water surface using paper strips. After the boiling procedure, the aggregate is removed from the beaker and the percentage of area coated with bitumen is visually assessed.

Currently the most widely spread method of testing bitumen-aggregate adhesion is the rolling bottle method according to the PN-EN 12697-11:2012 „Mieszanki mineralno-asfaltowe - Metody badania mieszanek mineralno-asfaltowych na gorąco - Część 11: Oznaczanie powinowactwa pomiędzy kruszywem i asfaltem / Bituminous mixtures. Test methods for hot mix asphalt. Determination of the affinity between aggregate and bitumen" standard. In this method a batch of clean and dry aggregate is uniformly coated with a thin film of bitumen. Coated aggregate is transferred into glass 
bottles filled with distilled water at $5^{\circ} \mathrm{C}$. Finally, the aggregate is transferred to the test bottles. Bottles are placed in the rolling machine (set to a rotational speed depending on the penetration of the tested bitumen) for 24 hours; during the procedures the percentage of coated area is assessed after 6 and 24 hours.

\subsection{DEVELOPMENT OF COMPUTER IMAGE ANALYSIS METHOD}

Computer image analysis [19] is a field of computer science devoted to extraction of meaningful information from images. In this study the percentage of aggregate's particle surface coated with bitumen was computed based on aggregate images captured with the help of the setup shown in Fig. 2. The computation was conducted by a custom piece of software called DISCO (Decent Inexpensive Script Computing Opacity) which has been developed in Wolfram Mathematica for the purpose of the study. The cut-off threshold which assigns each pixel's value as either coated or clean is based on the calibration readouts for aggregate samples which are either fully or not at all coated. This approach allows to remove human bias from the decision loop. Special attention was placed to properly differentiate black spots (minerals) on granite particles from bitumen binder.

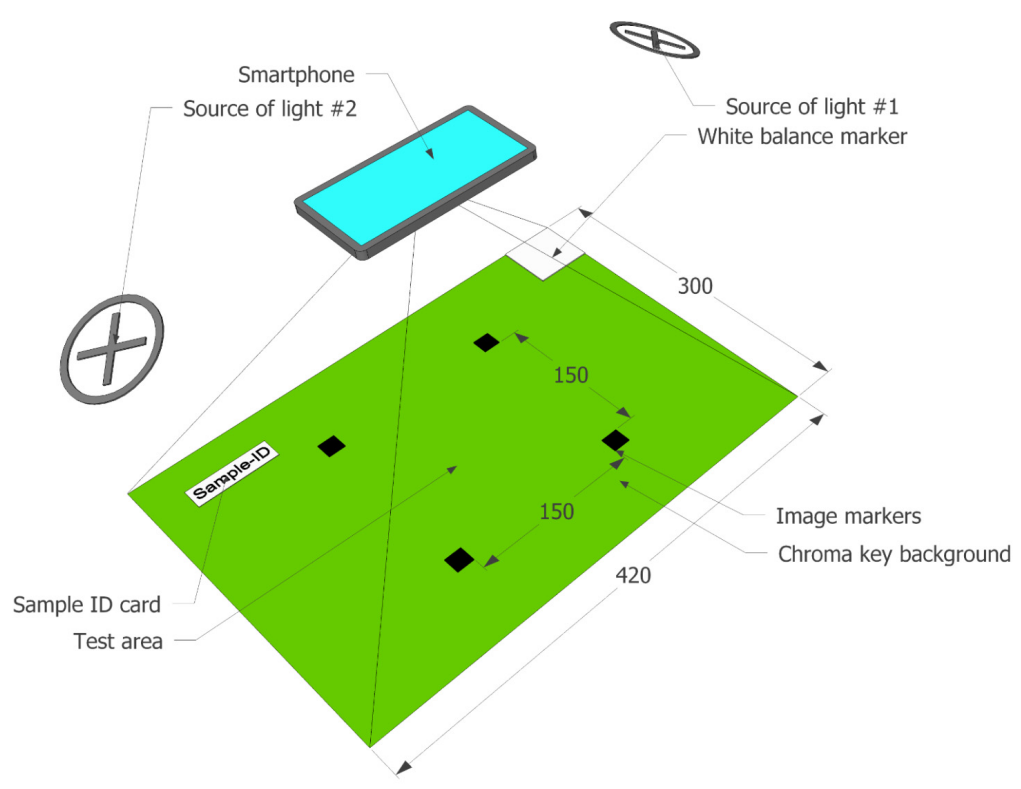

Fig. 2. Image capture setup 
Since the spacing between the image markers shown in Fig. 2 is known, application of a photographic reference scale was not required. Image generated by the software is shown in Fig. 3 . It consists of three distinctive parts, a reference image on the right for debugging, a resultant image of the analysis on the left [15], and a data signature in the bottom, which contains the sample ID, percentage of area covered with bitumen and an aggregate pixel count. The software written for the purpose of this study allows for batch analysis and automatically exports a raw .txt file with an ID data pair.

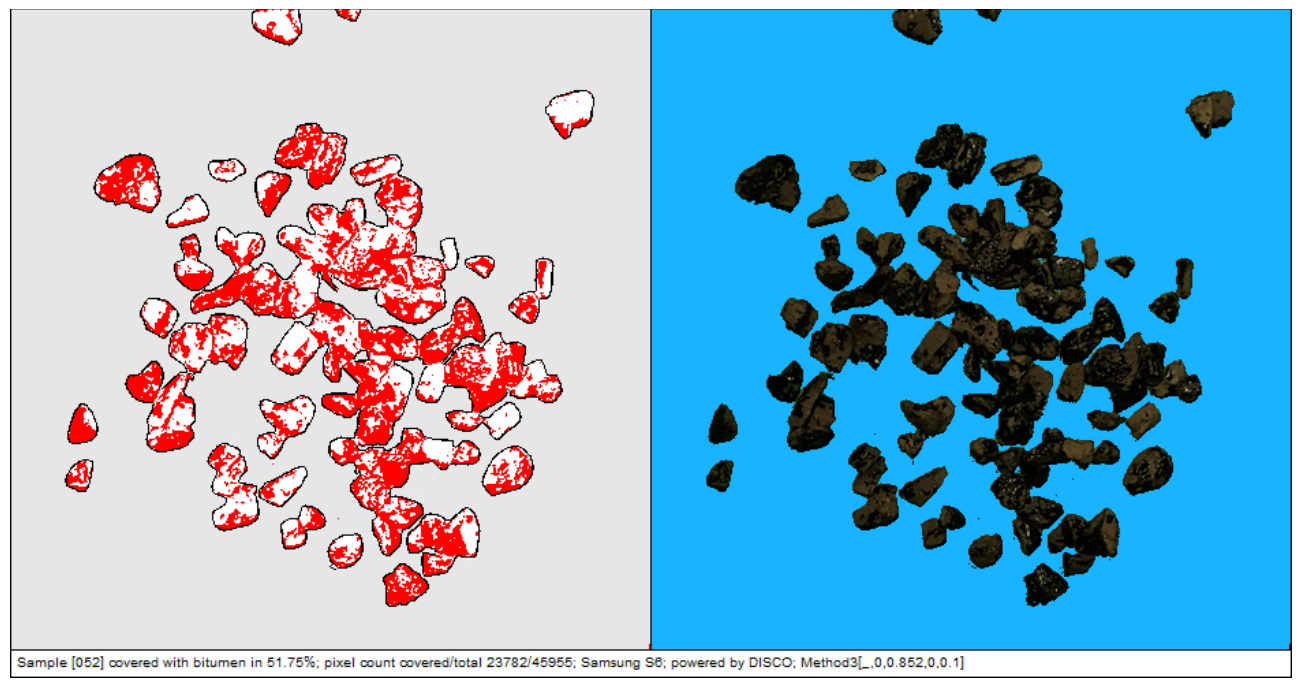

Fig. 3. Sample after adhesion test and their image generated by the DISCO script for further computations

\section{RESULTS AND ANALYSIS}

The presentation of test results obtained during this study was divided into three different parts: boiling water method, rolling bottle method (after 6 hours and after 24 hours of rolling) and part three statistical analysis and methods comparison. Merged test data is shown in Table 1. 
Table 1. Adhesion test results for all samples

\begin{tabular}{|c|c|c|c|c|c|c|}
\hline No & Aggregate & $\begin{array}{c}\text { Bitumen } \\
-\end{array}$ & $\begin{array}{c}\text { Degree of bitumen coverage in each } \\
\text { sample } \\
\{\%\}\end{array}$ & $\begin{array}{c}\text { Mean } \\
\%\end{array}$ & $\begin{array}{c}\text { Standard } \\
\text { deviation } \\
\%\end{array}$ & $\begin{array}{c}\text { Sample } \\
\text { size } \\
-\end{array}$ \\
\hline \multicolumn{7}{|c|}{ Boiling water method } \\
\hline 1 & Granite $4 / 6,3$ & $50 / 70$ raw & $\{40.33,56.10,70.59,67.98,60.39,53.57\}$ & 58.16 & 10.95 & 6 \\
\hline 2 & Granite $4 / 6,3$ & $50 / 70+5 \% \mathrm{~A}$ & $\{31.93,36.74,42.08,35.19,34.31,40.74\}$ & 36.83 & 3.89 & 6 \\
\hline 3 & Granite $4 / 6,3$ & $50 / 70+5 \% \mathrm{~B}$ & $\{41.73,28.43,40.92,41.62,43.87,36.09\}$ & 38.78 & 5.68 & 6 \\
\hline 4 & Limestone $4 / 6,3$ & $50 / 70$ raw & $\{57.95,46.62,49.31,70.84,52.73,51.75\}$ & 54.87 & 8.69 & 6 \\
\hline 5 & Limestone $4 / 6,3$ & $50 / 70+5 \% \mathrm{~A}$ & $\{38.64,41.92,47.04,44.63,41.87,46.97\}$ & 43.51 & 3.30 & 6 \\
\hline 6 & Limestone $4 / 6,3$ & $50 / 70+5 \% \mathrm{~B}$ & $\{37.80,45.34,47.40,48.02,48.71,45.72\}$ & 45.50 & 3.99 & 6 \\
\hline \multicolumn{7}{|c|}{ Rolling bottle method after $6 \mathrm{~h}$} \\
\hline 1 & Granite $4 / 6,3$ & $50 / 70$ raw & $\{53.33,71.64,74.70,63.23,62.36,61.65\}$ & 64.49 & 7.66 & 6 \\
\hline 2 & Granite $4 / 6,3$ & $50 / 70+5 \% \mathrm{~A}$ & $\{66.69,68.18,68.77,70.54,69.78,71.32\}$ & 69.21 & 1.68 & 6 \\
\hline 3 & Granite 4/6,3 & $50 / 70+5 \% \mathrm{~B}$ & $\{55.72,69.64,68.44,61.46,62.66,53.88\}$ & 61.97 & 6.41 & 6 \\
\hline 4 & Limestone $4 / 6,3$ & $50 / 70$ raw & $\{60.08,71.81,72.15,76.97,74.92,72.25\}$ & 71.36 & 5.88 & 6 \\
\hline 5 & Limestone $4 / 6,3$ & $50 / 70+5 \% \mathrm{~A}$ & $\{64.70,74.25,73.16,73.94,74.09,75.26\}$ & 72.57 & 3.91 & 6 \\
\hline 6 & Limestone $4 / 6,3$ & $50 / 70+5 \% \mathrm{~B}$ & $\{68.65,73.50,75.23,78.54,79.34,77.54\}$ & 75.47 & 3.97 & 6 \\
\hline \multicolumn{7}{|c|}{ Rolling bottle method after $24 \mathrm{~h}$} \\
\hline 1 & Granite $4 / 6,3$ & $50 / 70$ raw & $\{46.02,47.56,45.83,46.45,65.15,34.69\}$ & 47.62 & 9.81 & 6 \\
\hline 2 & Granite 4/6,3 & $50 / 70+5 \% \mathrm{~A}$ & $\{55.97,56.01,54.02,56.55,58.45,57.69\}$ & 56.45 & 1.54 & 6 \\
\hline 3 & Granite $4 / 6,3$ & $50 / 70+5 \% \mathrm{~B}$ & $\{43.18,43.05,44.55,42.49,44.64,41.78\}$ & 43.28 & 1.13 & 6 \\
\hline 4 & Limestone $4 / 6,3$ & $50 / 70$ raw & $\{49.76,60.63,61.00,61.91,63.19,65.90\}$ & 60.40 & 5.54 & 6 \\
\hline 5 & Limestone 4/6,3 & $50 / 70+5 \% \mathrm{~A}$ & $\{61.40,60.57,60.29,63.96,66.37,63.47\}$ & 62.68 & 2.35 & 6 \\
\hline 6 & Limestone $4 / 6,3$ & $50 / 70+5 \% \mathrm{~B}$ & $\{60.42,65.82,68.45,69.43,69.37,70.60\}$ & 67.35 & 3.75 & 6 \\
\hline
\end{tabular}

\subsection{BOILING WATER METHOD}

Fig. 4 presents the distribution of measurements for the boiling water method based on the results shown in Table 1. Going from the left to right one can observe the results of raw bitumen coated granite and limestone, followed by granite and limestone coated with bitumen modified with a 5\% PE based modifier, finishing with granite and limestone coated with the modified 5\% PE based copolymer. The box chart distributions for the modified bitumens are tighter, probably due to the increased hardness of the modified bitumens. 


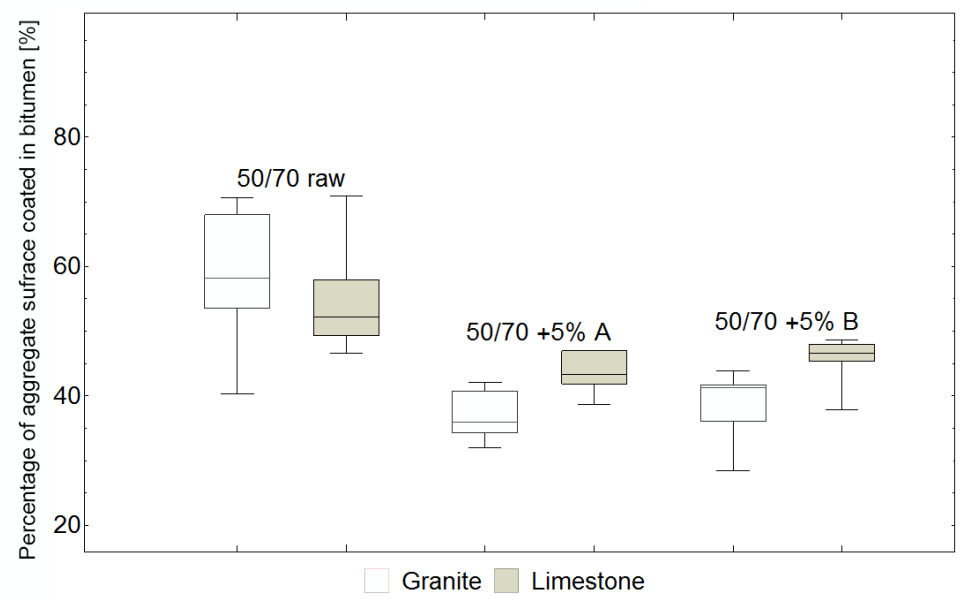

Fig. 4. Boiling water method test results

Fig. 5 presents the average adhesion based on the boiling water method. The modified samples present lower adhesion in comparison to the unmodified samples. Moreover alkaline aggregate displays higher adhesion to aggregate as compared to acidic aggregates (for the same kind of bitumen used). The higher adhesion of granite in case of the unmodified binder most likely is a pure coincidence and base on the Table 3 that finding has no statistical significance.

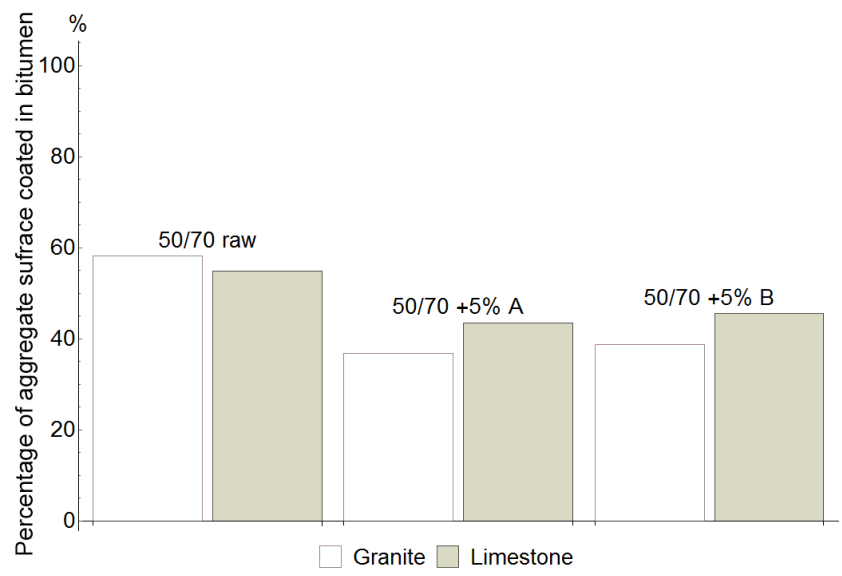

Fig. 5. Boiling water method mean test results 
All results obtained from the boiling water method passed the two sample t-test for equal means (Table 2), and as such may be used for measuring the influence of bitumen PE modification on the adhesive properties of the bitumen.

\subsection{ROLLING BOTTLE METHOD}

Fig. 6 presents the distribution of measurements for the boiling water method. Again, going from the left to right one can observe distribution of the adhesion test results of raw bitumen coated granite and limestone, followed by granite and limestone coated with bitumen modified with a $5 \%$ PE based modifier, finishing with granite and limestone coated with the modified 5\% PE based copolymer. In the case of the rolling bottle tests, the distributions of results vary and no distinctive pattern can be observed. Additionally, the PE modified bitumens present similar adhesion results to the unmodified samples.

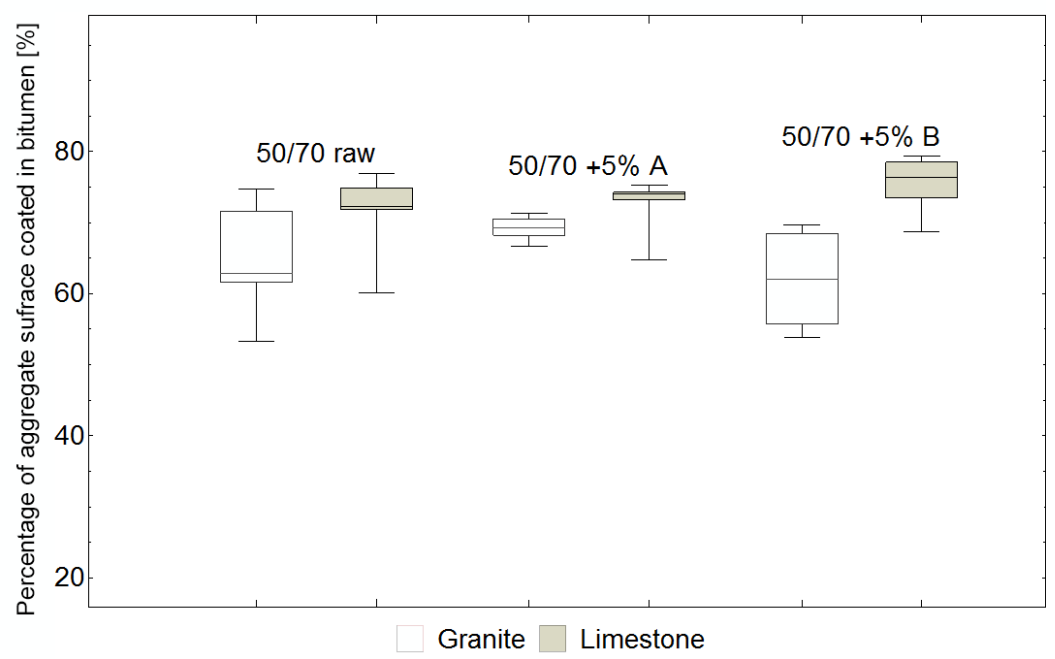

Fig. 6. Rolling bottle method: results after $6 \mathrm{~h}$ of testing

Fig. 7 presents the average adhesion based on the rolling bottle method after 6 hours. The modified samples present similar adhesion to the unmodified samples. Based on the adhesion results after $6 \mathrm{~h}$ of rolling, one could not distinguish the modified bitumens from the unmodified samples, based solely on the adhesion. 


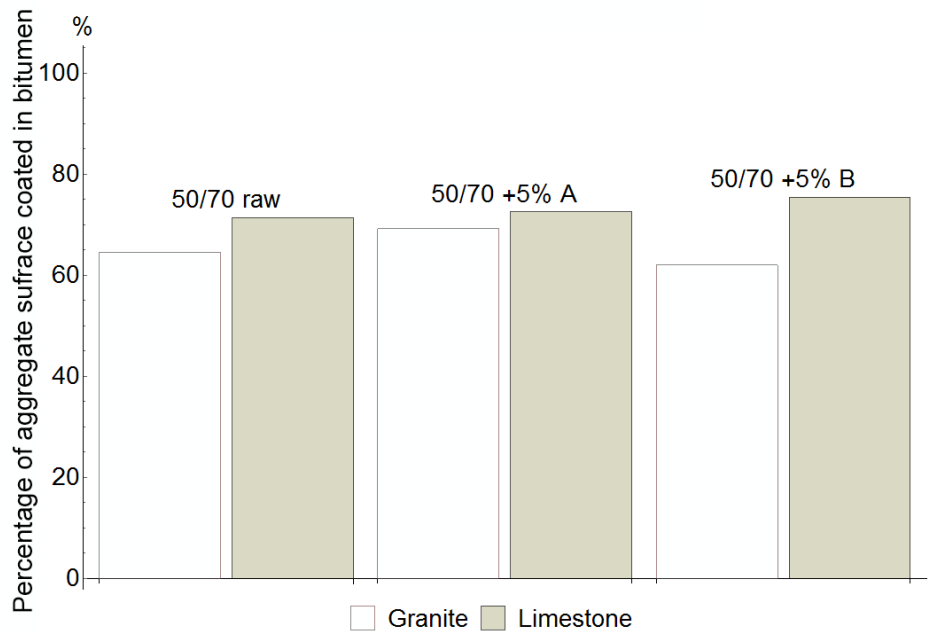

Fig. 7. Rolling bottle method: mean results after 6 h of testing

Fig. 8 presents the distribution of measurements for the bottle rolling method after 24 hours of testing, based on the results obtained from Table 1. Once more, going from the left to right one can observe the results of raw bitumen coated granite and limestone, followed by granite and limestone coated with bitumen modified with a 5\% PE based modifier, finishing with granite and limestone coated with the modified 5\% PE based copolymer. After additional 18 hours of rolling, the results seem to converge into a denser distribution.

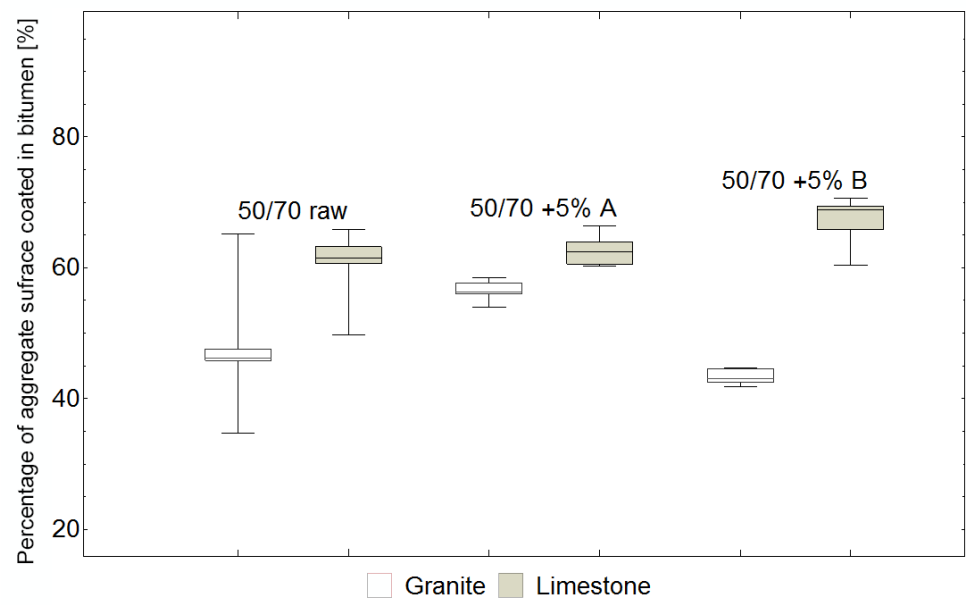

Fig. 8. Rolling bottle method: results after $24 \mathrm{~h}$ of testing 
Fig. 9 presents the average adhesion based on the rolling bottle method after 24 hours. The resultant adhesion varies greatly between tested samples. In terms of all samples after $24 \mathrm{~h}$ of rolling, the acidic aggregates scores lower in terms of adhesion in comparison to the alkali aggregate.

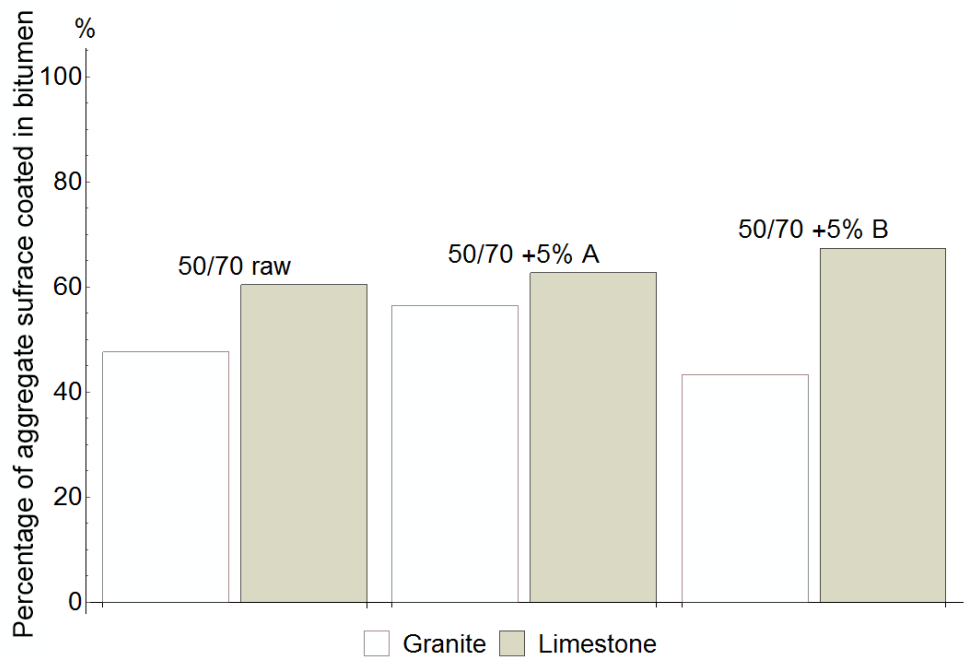

Fig. 9. Rolling bottle method: mean results after $24 \mathrm{~h}$ of testing

The statistical analysis of the results acquired after 6 and 24 hours of the rolling bottle test (Table 2) showed that only one measurement presents statistical significance in terms of cross-bitumen adhesion comparison. Similarly to the results visible in Fig. 7, the finding from Fig. 9 which were based on the Table 2 prohibits from using the bottle method results as a metric for cross-bitumen adhesion comparison.

\subsection{STATISTICAL ANALYSIS AND METHODS COMPARISON}

The results from all 108 measurements were tested for statistical soundness using two sample t-test [16] $(\alpha=0,05)$ for equal means based on the t-distribution with 10 degrees of freedom, as sketched in Fig. 10 (based on the two sample t-test formula). If the $p$-value is lower than $\alpha=0,05$, then it may be assumed with a $95 \%$ confidence interval (CI) that the result is true. 


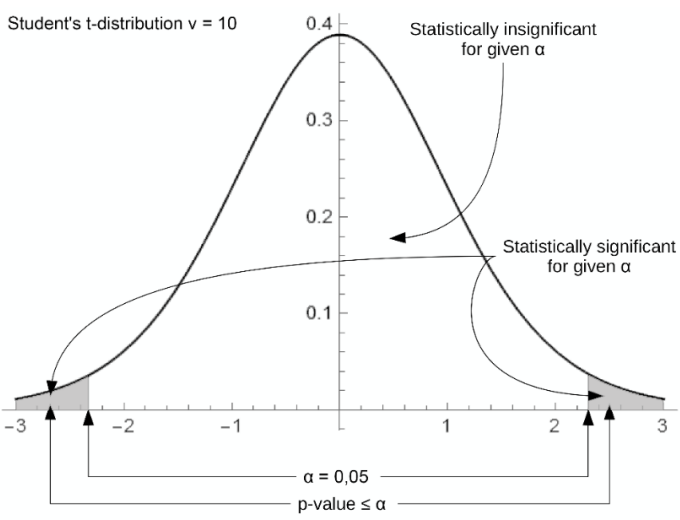

Fig. 10. Student's t-distribution with 10 degrees of freedom

For the cross-bitumen adhesion, test analyses if there is any statistically significant difference between the adhesion results of reference samples and the samples with modified bitumen. Following statistical tests were conducted:

1 - granite \& 50/70 raw bitumen vs. granite \& 50/70 +5\% A modified bitumen, 2 - granite $\& 50 / 70$ raw bitumen vs. granite $\& 50 / 70+5 \%$ B modified bitumen,

3 - limestone \& 50/70 raw bitumen vs. limestone \& 50/70 +5\% A modified bitumen,

4 - limestone \& 50/70 raw bitumen vs. limestone \& 50/70 +5\% B modified bitumen.

Results of the cross-bitumen adhesion comparison are shown in the Table 2.

Table 2. Two-sample t-test for cross-bitumen adhesion comparison

\begin{tabular}{|c|c|c|c|c|c|c|}
\hline \multirow{2}{*}{$\begin{array}{l}\text { Test } \\
\text { No }\end{array}$} & \multicolumn{2}{|c|}{ Boiling water method } & \multicolumn{2}{|c|}{ Rolling bottle method after $6 \mathrm{~h}$} & \multicolumn{2}{|c|}{ Rolling bottle method after $24 \mathrm{~h}$} \\
\hline & $\begin{array}{c}\text { p-value } \\
\%\end{array}$ & $\begin{array}{c}\text { Statistical } \\
\text { significance }\end{array}$ & $\begin{array}{c}\text { p-value } \\
\%\end{array}$ & $\begin{array}{c}\text { Statistical } \\
\text { significance }\end{array}$ & $\begin{array}{c}\text { p-value } \\
\%\end{array}$ & $\begin{array}{c}\text { Statistical } \\
\text { significance }\end{array}$ \\
\hline 1 & 0,11 & YES & 17,09 & NO & 5,44 & $\mathrm{NO}$ \\
\hline 2 & 0,32 & YES & 55,11 & NO & 30,77 & NO \\
\hline 3 & 1,35 & YES & 68,53 & NO & 37,62 & NO \\
\hline 4 & 3,73 & YES & 18,73 & NO & 2,93 & YES \\
\hline
\end{tabular}

The cross-aggregate adhesion comparison focuses on statistically significant differences in measured adhesion for different kinds of aggregate. Based on the t-test presented in Table 3, it can be observed that only the results of the rolling bottle method (after 24h) bare statistical significance in case of all three comparisons. This results suggest that hardness of aggregate might have high 
influence on the results of the rolling bottle method test.

Following statistical tests were conducted:

1 - granite \& 50/70 raw bitumen vs. limestone \& 50/70 raw bitumen,

2 - granite \& 50/70 +5\% A modified bitumen vs. limestone \& 50/70 +5\% A modified bitumen,

3 - granite \& 50/70 +5\% B modified bitumen vs. limestone \& 50/70 +5\% B modified

Results of the cross-aggregate adhesion comparison are shown in the Table 3.

Table 3. Two-sample t-test for cross-aggregate adhesion comparison

\begin{tabular}{|c|c|c|c|c|c|c|}
\hline \multirow{2}{*}{$\begin{array}{c}\text { Test } \\
\text { no }\end{array}$} & \multicolumn{2}{|c|}{ Boiling water method } & \multicolumn{2}{|c|}{ Rolling bottle method after $6 \mathrm{~h}$} & \multicolumn{2}{|c|}{ Rolling bottle method after $24 \mathrm{~h}$} \\
\hline & $\begin{array}{c}\text { p-value } \\
\%\end{array}$ & $\begin{array}{c}\text { Statistical } \\
\text { significance }\end{array}$ & $\begin{array}{c}\text { p-value } \\
\%\end{array}$ & $\begin{array}{c}\text { Statistical } \\
\text { significance }\end{array}$ & $\begin{array}{c}\text { p-value } \\
\%\end{array}$ & $\begin{array}{c}\text { Statistical } \\
\text { significance }\end{array}$ \\
\hline 1 & 57,66 & NO & 11,19 & NO & 1,95 & YES \\
\hline 2 & 0,94 & YES & 8,26 & NO & 0,02 & YES \\
\hline 3 & 3,92 & YES & 0,13 & YES & 0,00 & YES \\
\hline
\end{tabular}

\section{CONCLUSIONS}

Proper bitumen-aggregate adhesion plays a vital role in pavement durability. In this paper determination of the influence of polyethylene modification on the adhesive properties of modified bitumen was studied. Based on the cross-bitumen adhesion results it can be concluded that addition of polyethylenes to bitumens has a negative effect on the latter's adhesion with aggregate. Due to the fact that seven out of eight tests (rolling bottle method) turned out to be statistically insignificant (by statistical significance it is understand that the registered differences between the modified sample and the control sample are small) and as such could not be used to draw conclusion as to the effects of PE modification on bitumen adhesion in the light of the t-test. Moreover, they were not used to further determine the effects of polyethylene modification on bitumen adhesion. Based on the cross-aggregate adhesion results of the rolling bottle method, it seems to be clear that the type of used aggregate has an effect on the registered adhesion. The granite samples which represent acidic aggregates are substantially harder (6-7 on the Mohs scale) than the alkaline limestone (2-3 on Mohs scale). As of this moment, PE modification seems to worsen the adhesion between bitumen and aggregate. The rolling bottle method's results tend to reflect the abrasive properties of the used aggregate, and not the aggregate - bitumen adhesion. 


\section{REFERENCES}

1. Mutiu AKINPELU, Bamidele I. O. DAHUNSI, Oladipupo OLAFUSI, Olufemi AWOGBORO, Adedeji QUADRI; Effect of polythene modified bitumen of properties of hot mix asphalt; ARPN Journal of Engineering and Applied Sciences, Vol. 8 No. 4, 2013, ISSN 1819-6608; 290 - 295.

2. Wojciech BAŃKOWSKI, Marcin GAJEWSKI; Accelerated loading tests in the full scale on innovative pavement structures; Roads and Bridges - Drogi i Mosty, no 2, 2012; pp. 89-121.

3. Yvonne BECKER, Maryro P. MÉNDEZ, Yajaira RODRÍGUEZ; Polymer modified asphalt; Vision tecnologica, Vol. 9 No. 1, 2001; $39-50$.

4. Marcin BŁASZCZAK, Karol J. KOWALSKI, Jan KRÓL; Friction coefficient, texture depth and tyre/road noise evaluation method by analysis of tyre print image; Roads and Bridges - Drogi i Mosty, no 14, 2015; 85 100.

5. Dariusz BROŻYNA, Karol J. KOWALSKI; Modification of asphalt binders by polyethylene-type polymers; Journal of Building Chemistry, 2016; DOI: 10.17461/j.buildchem.2016.106; 37-41.

6. Shuang CUI, Bamber R. K. BLACKMAN, Anthony J. KINLOCH, Ambrose C. TAYLOR; Durability of asphalt mixtures: Effect of aggregate type and adhesion promoters; International Journal of Adhesion and Adhesives 54, 2014; 100 - 111 .

7. S. Hassan FIROOZIFAR, Yashar A. ALAMDY, Orang FARZANEH; Investigation of novel methods to improve the storage stability and low temperature susceptivity of polyethylene modified bitumens; Petroleum \& Coal 52 (2) ISSN 1337-7027, 2010; 123 - 128.

8. Irena GAWEŁ, J. PIŁAT, K. J. KOWALSKI, J. B. KRÓL; Rubber modified bitumen; in Polymer modified bitumen, Woodhead Publishing, 2011; 72-97. DOI: 10.1533/9780857093721.1.72.

9. Arno Wilhelm HEFER; Doctoral dissertation; Adhesion in bitumen-aggregate systems and quantification of the effects of water on the adhesive bond; Texas A\&M University; December 2014.

10. Jan KRÓL; Nowa metoda analizy mikrostruktury asfaltów modyfikowanych polimerami; Drogi i Mosty, no 4, $2008 ; 23-4$.

11. Jan KRÓL, Jerzy PIŁAT, Michał SARNOWSKI, Wioleta CZARNACKA; Ocena adhezji asfaltów modyfikowanych do kruszyw mineralnych; Magazyn Autostrady, no. 10, 2010; 88-92.

12. Jan B. KRÓL, Karol J. KOWALSKI, Piotr RADZISZEWSKI, Michał SARNOWSKI; Rheological behaviour of n-alkane modified bitumen in aspect of Warm Mix Asphalt technology, Construction and Building Materials, vol. 93, 2015, pp. 703-710. DOI:10.1016/j.conbuildmat.2015.06.033.

13. Karol J. KOWALSKI, Andrzej J. BRZEZIŃSKI, Jan B. KRÓL, Piotr RADZISZEWSKI, Łukasz SZYMAŃSKI; Traffic analysis and pavement technology as a tool for urban noise control; Archives of Civil Engineering; is. 4; vol. LXI, 2015; pp. 107-125; DOI: 10.1515/ace-2015-0039.

14. Mariola KSIĄŻEK, Paweł NOWAK, Serkan KIVRAK, Jerzy H. ROSŁON, Leonas USTINOVICHIUS; Computer-aided decision-making in construction project development; Journal of Civil Engineering and Management; vol. 21, is. 2, 2015; pp. 248-259.

15. Gyurim LEE; Study of psychology of achromatic colors; Hanyang University, 2015.

16. Piotr RADZISZEWSKI, K. J. KOWALSKI, J. B. KRÓL, M. SARNOWSKI, J. PIŁAT, Quality assessment of bituminous binders based on the viscoelastic properties: Polish experience; Journal of Civil Engineering and Management, vol. 20, no. 1, 2014, 111-120. DOI: 10.3846/13923730.2013.84358.

17. Deborah RUMSEY; Statistics Essentials For Dummies; Wiley Publishing, Inc.; ISBN: 978-0-470-61839-4, 2010 .

18. Michał SARNOWSKI; Doctoral dissertation; Influence of bitumen binders and asphalt mixtures modifications on rheological and adhesion properties; Warsaw University of Technology; April 2011.

19. Richard SZELISKI; Computer Vision: Algorithms and Applications; Springer; ISBN-10: 1848829345; 2011

20. Elżbieta TRZASKA; Adhezja asfaltu do kruszywa, NAFTA-GAZ 6/2011; 423 - 427.

21. Ali Akbar YOUSEFI; Polyethylene Dispersion in Bitumen: The Effects of the Polymer Structural Parameters; Journal of Applied Polymer Science, no 12, 2003; 3183 - 3190.

22. Artur ZBICIAK, Karol BRZEZIŃSKI \& Rafał MICHALCZYK; Constitutive models of pavement asphaltic layers based on mixture compositions; Journal of Civil Engineering and Management, 2016; DOI: $10.3846 / 13923730.2015 .1128483$. 


\section{LIST OF FIGURES AND TABLES}

Fig. 1. Research flowchart

Rys. 1. Schemat blokowy badań

Fig. 2. Image capture setup

Rys. 2. Stanowisko do rejestrowania obrazu

Fig. 3. Sample after adhesion test and their image generated by the DISCO script for further computations

Rys. 3. Próbka po badaniu adhezji i jej obraz uzyskany za pomocą skryptu DISCO do dalszych obliczeń

Fig. 4. Boiling water method test results

Rys. 4. Wyniki badania metodą gotowania

Fig. 5. Boiling water method mean test results

Rys. 5. Średnie wyniki badania metodą gotowania

Fig. 6. Rolling bottle method: results after $6 \mathrm{~h}$ of testing

Rys. 6. Wyniki badania metodą butelkową po $6 \mathrm{~h}$

Fig. 7. Rolling bottle method: mean results after $6 \mathrm{~h}$ of testing

Rys. 7. Średnie wyniki badania metodą butelkową po $6 \mathrm{~h}$

Fig. 8. Rolling bottle method: results after $24 \mathrm{~h}$ of testing

Rys. 8. Wyniki badania metodą butelkową po $24 \mathrm{~h}$

Fig. 9. Rolling bottle method: mean results after $24 \mathrm{~h}$ of testing

Rys. 9. Średnie wyniki badania metodą butelkową po $24 \mathrm{~h}$

Fig. 10. Student's t-distribution with 10 degrees of freedom

Rys. 10. Rozkład t-studenta z 10 stopniami swobody

Tab. 1. Adhesion test results for all samples

Tab. 1. Wyniki badania adhezji dla wszystkich próbek

Tab. 2. Two-sample t-test for cross-bitumen adhesion comparison

Tab. 2. Test t-studenta dla dwóch próbek - porównanie pomiędzy lepiszczami

Tab. 3. Two-sample t-test for cross-aggregate adhesion comparison

Tab. 3. Test t-studenta dla dwóch próbek - porównanie pomiędzy kruszywami 


\section{ZASTOSOWANIE KOMPUTEROWEJ ANALIZY OBRAZU DO OCENY ADHEZJI LEPISZCZY ASFALTOWYCH MODYFIKOWANYCH POLIETYLENEM}

Stowa kluczowe: asfalt, modyfikacja, adhezja, komputerowa analiza obrazu, polietylen, plastomer, kopolimer

\section{STRESZCZENIE:}

W związku ze stale rosnącą wielkością ruchu drogowego, dla prawidłowego rozwoju gospodarki, niezbędna jest budowa trwałych nawierzchni drogowych. Jednym ze sposobów osiągnięcia tego celu jest zastosowanie wysokiej jakości mieszanek mineralno-asfaltowych (MMA). Mieszanki te są kompozytami kruszyw oraz lepiszczy asfaltowych. Tematyka adhezji pomiędzy lepiszczami a kruszywem była przedmiotem badań prezentowanych w wielu publikacjach, np. [6, 11, 18 and 20]. Stwierdzić należy, że stosunkowo mało uwagi zostało poświęcone tematyce wpływu modyfikacji lepiszczy asfaltowych polietylenami na ich adhezję do kruszyw [1].

Celem badań prezentowanych w artykule była oceny wpływu modyfikacji lepiszczy asfaltowych polietylenami na zjawisko adhezji pomiędzy kruszywem a lepiszczem. Metodyka badań została oparta na obecnych jak i wycofanych normach polskich (PN 84 B 06714/22 „Kruszywa mineralne. Badania. Oznaczanie przyczepności bitumów / Mineral aggregates. Tests. Assesment of bitumen adhesion”) oraz europejskich (PN-EN 12697-11:2012 „Mieszanki mineralnoasfaltowe -- Metody badania mieszanek mineralno-asfaltowych na gorąco -- Część 11: Oznaczanie powinowactwa pomiędzy kruszywem i asfaltem / Bituminous mixtures. Test methods for hot mix asphalt. Determination of the affinity between aggregate and bitumen"). W programie badawczym jako kruszyw użyto granitu oraz wapienia o uziarnieniu 4/6,3, które następnie otoczono lepiszczem asfaltowym. Zastosowano trzy różne rodzaje lepiszczy asfaltowych: jedno niemodyfikowane o penetracji 50/70 oraz dwa modyfikowane polietylenami oraz kopolimerami. Ilość użytego modyfikatora odpowiadała 5\% stężeniu (wagowo) w zmodyfikowanych lepiszczach. Po przeprowadzeniu badań zgodnie z diagramem (Rys. 1) przystąpiono do oceny stopnia otoczenia kruszywa. W przeciwieństwie do wytycznych normowych zrezygnowano z wizualnej oceny opartej o dwóch subiektywnych operatorów (analiza wzrokowa wykonywana przez człowieka), na rzecz w pełni zautomatyzowanego skryptu komputerowego Decent Image Script Computing Opacity - (DISCO). Skrypt został opracowany w środowisku Wolfram Mathematica i pozwala na automatyczny pomiar otoczenia kruszywa. Na diagramie Rys. 2 przedstawiono stanowisko pomiarowe rejestracji obrazu natomiast na Rys. 3 przestawiono obraz generowany przez skrypt DISCO. W tabeli 1 zestawiono wszystkie pomiary dokonane w trakcie badań, na postawie których utworzono wykresy pudełkowe przestawiające rozkład pomiarów oraz wykresy słupkowe przestawiające średnią adhezję dla poszczególnych próbek po każdym z testów (Rys. 4-9). Na podstawie tych wyników przeprowadzono analizę statystyczną w oparciu o test t-Studenta dla prób niezależnych. Przyjęty poziom istotności wynosił $\alpha=0,05$.

Zgodnie z przewidywaniami teorii wiązań chemicznych jak i elektrostatycznej [9], odnotowano spadek adhezji lepiszczy do kruszyw po przeprowadzeniu modyfikacji polietylenami. Do oceny wpływu modyfikacji lepiszcza na adhezję posłużono się jedynie wynikami testu gotowania (PN-84 B-06714/22), gdyż wyniki testu butelkowego (PN-EN 12697-11:2012), nie przekroczyły wartości krytycznej użytego testu t-Studenta (Tab. 2). Porównanie wyników adhezji w obrębie tej samej modyfikacji wykazało, iż w przypadku testu butelkowego (PN-EN 12697-11:2012) czynnikiem decydującym może być twardość kruszywa. W celu potwierdzenia tego przypuszczenia koniecznym byłoby przeprowadzenie osobnego programu badawczego. 